\title{
THE MICRO- AND NANOSECOND DISCHARGES IN GAS BUBBLES FOR WATER DISINFECTION AND PURIFICATION
}

Purpose. Comparison of electrical circuits of experimental plants for obtaining micro- and nanosecond discharges in gas bubbles in water and comparing the experimental results obtained for disinfecting water using such discharges. Methodology. To obtain high-voltage pulses on the load in the form of a gas bubbles and a layer of water with a frequency of more than 2000 pulses per second, a method of generating micro- and nanosecond pulses using high-voltage pulse generators based on a pulse transformer (PT) according to Tesla, with a transistor opening switch IGBT in the low-voltage part of the circui . A current-limiting resistor with a resistance $R_{c l}=24 \mathrm{k} \Omega$ is used to protect the transistor switch at microsecond discharges. At nanosecond discharges, a multi-gap spark gap is used to sharpen the front of high-voltage pulses. We used a capacitive voltage divider with a division factor of $K_{d}=7653$ to measure voltage pulses, a shunt with a resistance of $R_{s}=2.5 \Omega$ for measuring current pulses. RIGOL DS1102E digital oscilloscope with a $100 \mathrm{MHz}$ bandwidth was used as a recording device. Results. The effect of micro- and nanosecond discharges in gas bubbles on microorganisms was experimentally investigated. It was possible to reduce the biochemical oxygen consumption of water during microsecond discharges, reduce the turbidity of water, and improve its organoleptic qualities. The energy released in a single pulse with microsecond discharges $W_{\mu} \approx 17 \mathrm{~mJ}$, with nanosecond discharges $W_{n} \approx 7.95 \mathrm{~mJ}$. At nanosecond discharges, complete inactivation of E.coli bacteria was achieved. The disinfecting and purifying action of nanosecond pulses is better compared to microsecond pulses due to an increase in the amplitude of the pulsed voltage up to $30 \mathrm{kV}$, and a pulsed current of up to 35 A. Originality. The possibility of effective microbiological disinfection of water using nanosecond discharges in gas bubbles at low specific energy consumption has been experimentally shown. Practical value. The obtained experimental results on water disinfection using micro- and nanosecond discharges offer the prospect of industrial application of installations using such discharges for disinfecting and purification wastewater, swimming pools, and posttreatment of tap water. References 9, figures 3.

Key words: high-voltage generator, micro- and nanosecond pulses, discharge in gas bubbles in water, disinfection and water purification by discharges, inactivation of microorganisms.

Мета. Порівняння електричних кіл експериментальних установок для одерэсання мікро- та наносекундних розрядів в газових бульках у воді і порівняння одержаних експериментальних результатів знезараження води за допомогою таких розрядів. Методика. Для отримання високовольтних імпульсів на навантаженні у вигляді бульок газу і шару води з частотою більше 2000 імпульсів за секунду запропоновано спосіб генерації мікро- та наносекундних імпульсів 3 використанням генераторів імпульсів високої напруги на основі імпульсного трансформатора за схемою Тесла 3 транзисторним розмикаючим перемикачем IGBT в низьковольтній частині кола. Резистор, цио обмежує струм, 3 опором $R_{c l}=24$ кОм використовується для захисту транзисторного перемикача при мікросекундних розрядах. При наносекундних розрядах багатозазорний іскровий розрядник використовується для загострення фронту імпульсів високой напруги. Ми використовували смнісний дільник напруги 3 коефіцієнтом ділення $\mathrm{K}_{d}=7653$ для вимірювання імпульсів напруги, иунт з опором $R_{s}=2,5$ Ом - для вимірювання імпульсів струму. В якості записуючого пристрою використовувався цифровий осцилограф RIGOL DS1102E зі смугою пропускання 100 МГц. Результати. Експериментально досліджено вплив мікро- $і$ наносекундних розрядів в газових бульках на мікроорганізми. Вдалося зменшити біохімічне споживання кисню водою при мікросекундних розрядах, знизити мутність води, покращити органолептичні показники. Енергія, щцо виділясться в одному імпульсі при мікросекундних розрядах, складає $W_{\mu} \approx 17$ мДж, а при наносекундних розрядах - $W_{n} \approx 7,95$ мДж. При наносекундних розрядах досягнуто повної інактивації бактерій E.coli. Знезаражуюча $і$ очищуюча дія наносекундних імпульсів краца порівняно 3 мікросекундними імпульсами із-за збільщення амплітуди імпульсної напруги до 30 кВ, а імпульсного струму до 35 А. Наукова новизна. Експериментально показана можливість ефективного мікробіологічного знезараження води за допомогою наносекунднх розрядів в газових бульках при малих питомих витратах енергї. Практична значущість. Одержані експериментальні результати щцод знезараження води за допомогою мікро- $і$ наносекундних розрядів відкривають перспективу промислового застосування установок з використанням таких розрядів для знезараження $i$ очистки стічних вод, басейнів та доочистки водопровіднӧ̈ води. Бібл. 9, рис. 3.

Ключові слова: високовольтний генератор, мікро- и наносекундні імпульси, розряд в газових бульках у воді, знезараження та очистка води розрядами, інактивація мікроорганізмів.

Цель. Сравнение электрических схем экспериментальных установок для получения микро- и наносекундных разрядов в газовых пузырях в воде и сравнение полученных экспериментальных результатов обеззараживания воды при помощи таких разрядов. Методика. Для получения высоковольтных импульсов на нагрузке в виде пузырьков газа и слоя воды с частотой более 2000 импульсов в секунду предложен способ генерации микро- и наносекундньх импульсов с использованием генераторов импульсов высокого напряжения на основе импульсного трансформатора по схеме Тесла с транзисторным размыкающим переключателем IGBT в низковольтной части цепи. Токоограничивающий резистор с сопротивлением $R_{c l}=24$ кОм используется для защиты транзисторного переключателя при микросекундных разрядах. При наносекундных разрядах многозазорный искровой разрядник используется для обострения фронта импульсов высокого напряжения. Мы использовали емкостный делитель напряжения с коэффициентом деления $K_{d}=7653$ для измерения импульсов напряжения, шунт с сопротивлением $R_{s}=2,5$ Ом - для измерения импульсов тока. В качестве записывающего устройства использовался цифровой осциллограф RIGOL DS1102E с полосой пропускания 100 МГц. Результаты. Экспериментально исследовано влияние микро- и наносекундных разрядов в газовых пузырях на

(C) M.I. Boyko, A.V. Makogon 
микроорганизмы. Удалось уменьшить биохимическое потребление кислорода воды при микросекундных разрядах, снизить мутность воды, улучшить органолептические показатели. Энергия, выделяемая в одном импульсе при микросекундных разрядах, составляет $W_{\mu} \approx 17$ мДюс, а при наносекундных разрядах - ${ }_{n} \approx 7,95$ мДэс. При наносекундных разрядах достигнута полная инактивация бактерий Е.соді. Обеззаражсивающее и очищающее действие наносекундных импульсов лучие по сравнению с микросекундными импульсами из-за увеличения амплитудь импульсного напряжения до 30 кВ, а импульсного тока до 35 А. Научная новизна. Экспериментально показана возможность эффективного микробиологического обеззаражсивания воды при помощци наносекундных разрядов в газовых пузырях при малых удельных затратах энергии. Практическая значимость. Полученные экспериментальные результаты по обеззараживанию воды при помощи микро- и наносекундных разрядов открывают перспективу промышленного применения установок с использованием таких разрядов для обеззаражсиваня и очистки сточных вод, бассейнов и доочистки водопроводной воды. Библ. 9, рис. 3.

Ключевые слова: высоковольтный генератор, микро- и наносекундные импульсы, разряд в газовых пузырях в воде, обеззараживание и очистка воды разрядами, инактивация микроорганизмов.

Introduction. In the modern world, researchers are constantly searching for new energy-saving technologies for disinfection and water treatment. One of the most promising and relevant technologies in this direction is the technology of water treatment using micro- and nanosecond discharges in gas bubbles [1-3].

The use of short electric pulses of voltage (current) for water treatment allows to avoid large ohmic losses due to its heating, to increase the electrical strength of the discharge gap, thereby obtaining high electric fields with intensity of $E \geq 30 \mathrm{kV} / \mathrm{cm}$ in a load in the form of a gas bubble water layer. High electric fields inactivate microorganisms in water, causing irreversible pore formation in the cell membranes of microorganisms, as well as affecting the intracellular contents, including the impact on their RNA and DNA [4].

Pulsed electrical discharge is also a source of broadband radiation. It follows from $[5,6]$ that such radiation has damaging effects on bacteria, leading to their degradation and destruction, and, thereby, increasing the efficiency of microbiological disinfection of water.

Micro- and nanosecond discharges in gas bubbles inside the treated volume of water cause the formation of active microparticles with a high value of oxidative potential, measured in volts. The highest value of the oxidation potential for ozone $\left(\mathrm{O}_{3}\right)$ is $2.07 \mathrm{~V}$, for atomic oxygen $(\mathrm{O})$ is $2.42 \mathrm{~V}$, for hydroxyl $(\mathrm{OH})$ is $2.85 \mathrm{~V}$, and for hydrogen peroxide $\left(\mathrm{H}_{2} \mathrm{O}_{2}\right)$ is $1.77 \mathrm{~V}$ [7].

Ozonation is widely used for disinfection of drinking water, as well as water in swimming pools. However, $\mathrm{OH}$ hydroxyls, which are formed in discharges in the presence of water, have a higher oxidative potential and are able to destroy persistent chemical compounds, unlike ozone [8]. The use of $\mathrm{OH}$ can improve the efficiency of disinfection and chemical treatment of water. The lifetime of $\mathrm{OH}$ particles in the air is hundreds of microseconds. Therefore, radicals should be created in the immediate vicinity of the surface of the separation of water and gas bubbles in it $[1,9]$.

Installations using this type of discharge can be widely used for the treatment of wastewater, waters of swimming pools and the purification of tap water.

The goal of the work is a comparison of the electrical circuits of experimental installations for obtaining micro- and nanosecond discharges in gas bubbles in water, as well as a comparison of the experimental results obtained for disinfecting water using such discharges.

Electric circuits of experimental installations. Figures $1, a, b$ show the electric circuits of experimental installations for water treatment using micro- and nanosecond discharges in gas bubbles $[2,3]$.

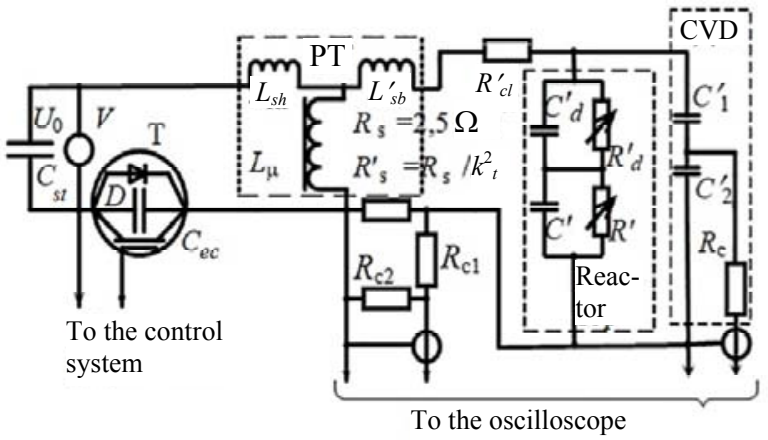

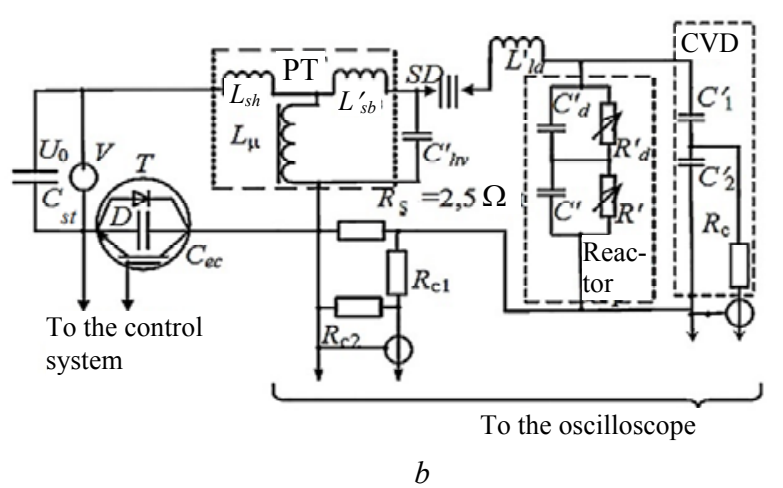

Fig. 1. Electric circuits of experimental water treatment plants using discharges in gas bubbles: $a$ - microsecond; $b$ - nanosecond

In Fig. $1, a, b$, the capacitance $C_{s t}$ is charged from the mains $(220 \mathrm{~V}, 50 \mathrm{~Hz})$ to the voltage $U_{0}$. T is the transistor switch of IGBT-transistors of type IRG4PH50UD, operating as a breaker. Pulse transformer (PT) according to the Tesla scheme is presented in the form of a equivalent circuit, where $L_{\mu}$ is the magnetization inductance; $L_{s h}, L_{s b}^{\prime}$ are the primary leakage inductance and reduced secondary leakage inductance; $D$ are the reverse diodes of the IGBT-key built into the transistors; $C_{e c} \geq 1 \mathrm{nF}$ is the «emitter collector» capacitance of the IGBT-key; $C_{d}^{\prime}<C_{e c}<<C_{s t} ; R_{s}^{\prime}$ is the reduced resistance of the measuring shunt in the high-voltage circuit of the generator; $R_{c 1}=300 \Omega, R_{c}=60 \Omega$ are the matching resistances of the shunt $R_{\mathrm{s}}=2.5 \Omega ; C^{\prime}{ }_{1}, C^{\prime}{ }_{2}$ are the reduced 
capacitances of high-voltage and low-voltage arms of capacitive voltage divider (CVD) with matching resistance $R_{c}$. Here, the unreduced (i.e. real) values of the capacitances were $C_{1} \approx 2.7 \cdot 10^{-12} \mathrm{~F}, C_{2}=20.4 \cdot 10^{-9} \mathrm{~F}$, and the division ratio of CVD is $K_{d} \approx 7650$. In the electric circuit of the reactor, $C_{d}, R_{d}$ are the capacitance and nonlinear active resistance of the discharge gap (DG), and $C, R$ are the capacitance and nonlinear resistance of the water layer between the DG and a low-voltage (grounded) electrode $\left(C_{d}^{\prime}, R_{d}^{\prime}, C^{\prime}, R^{\prime \prime}\right.$ are the reduced to the primary winding of PT values of these quantities), respectively.

Principal differences between the electric circuits of experimental installations. In the diagram in Fig. 1,a a current-limiting resistor with resistance $R_{c l}^{\prime}=24 \mathrm{k} \Omega$ is used to protect the transistor switch by current. The dissipation of active power on the resistor leads to additional ohmic losses. $C_{s t}=940 \mu \mathrm{F}$ ( 2 capacitors TAMICON $470 \mu \mathrm{F}$ in parallel), $T$ is the transistor switch consisting of 2 transistors connected in parallel. In the diagram in Fig. $1, b \quad C_{s t}=4230 \mu \mathrm{F}$ (9 capacitors TAMICON $470 \mu \mathrm{F}$ in parallel), the transistor switch $T$ consists of four parallel-connected transistors. The pulse duration, the front and the shape are determined by the discharge circuit $C_{h v}-S D-L_{l d}-\left(R_{d}\right.$ in parallel with $\left.C_{d}\right)-$ ( $R$ in parallel with $C$ ) $-R_{s h}-C_{h v}$. The sharpening of the pulse front occurs when a multichannel multigap spark discharger $S D$ operates. The distance between the gaps is $1 \mathrm{~mm}$, it is possible to adjust, the number $n$ of gaps is $1 \leq n \leq 5$. The pulse duration is determined by the presence in the discharge circuit of a low-inductance capacitive energy storage device $C_{h v}=150 \mathrm{pF}$ assembled from six КВИ-2 capacitors with capacitance of $100 \mathrm{pF}$ each, calculated for voltage $20 \mathrm{kV}$ (two consecutive chains of three capacitors in parallel). All voltage from $C_{h v}$ is applied to series-connected discharger $S D$ and discharge gap DG in the reactor - a gas bubble in water. The inductance $L_{l d}$ of the load discharge circuit is $L_{l d} \approx 0.5 \mu \mathrm{H}$.

Experimental results. Figures $2, a, b$ show oscillograms of voltage (current) pulses obtained at disinfecting water treatment using micro- and nanosecond discharges.
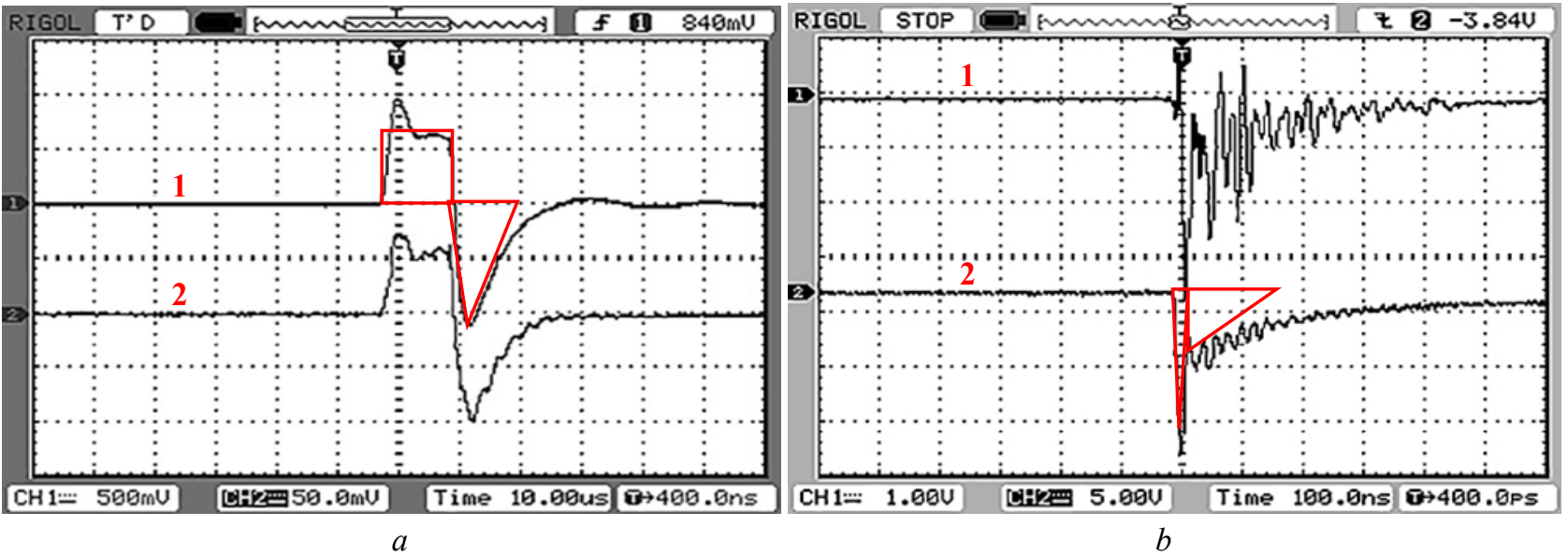

Fig. 2. Oscillograms of voltage (curves 1) and current (curves 2) pulses: $a-$ at microsecond discharges; $b-$ at nanosecond discharges

At microsecond discharges (see Fig. 2,a), the voltage amplitude reaches $8 \mathrm{kV}$, and the current amplitude is $0.2 \mathrm{~A}$ at a pulse repetition rate of $f \approx 2200$ $\mathrm{Hz}$. The division along the process axis is $4 \mathrm{kV} / \mathrm{div}$ for voltage oscillograms, and $0.1 \mathrm{~A} / \mathrm{div}$ for current oscillograms. Oscillograms of voltage and current in the load (in the form of a working chamber with water processed by microsecond discharges) have the shape of bipolar pulses.

At nanosecond discharges, the amplitude (see Fig. 2,b) of the voltage across the load reaches $30 \mathrm{kV}$, and the amplitude of the current is $35 \mathrm{~A}$ at a pulse repetition rate of $f \approx 2200 \mathrm{~Hz}$. The division along the process axis for voltage oscillograms is $7.9 \mathrm{kV} / \mathrm{div}$, and for current oscillograms it is $11.7 \mathrm{~A} / \mathrm{div}$. At nanosecond discharges, the shape of the voltage and current pulses in the load is close to the decaying exponent with a steep front and superimposed oscillations. A capacitive voltage divider with division factor $K_{d}=7653$ was used to register voltage pulses, and a shunt with resistance $R_{s}=2.5 \Omega\left(R_{c 1}=300 \Omega\right.$, $R_{c 2}=60 \Omega-$ matching shunt resistances) was used to register current pulses. A RIGOL DS1102E digital oscilloscope with a bandwidth of $100 \mathrm{MHz}$ was used as a recording device.

Current and voltage on the oscillograms of Fig. 2, $a, b$ are close in shape and practically not shifted relative to each other in time. In the first approximation, we can assume that the load is active and all the energy $W$ is released in the working chamber. Calculate the energy $W$, based on the relation of the form

$$
W=\int_{0}^{t} U(t) \cdot i(t) d t .
$$

For the estimated calculation of energy, we represent the positive part of the pulses in Fig. 2, $a$ in the form of two rectangular regions with sides along the time axis $t_{1} \approx 10 \mu \mathrm{s}$, and negative one in the form of two triangular regions with the same base size along the time axis $t_{2} \approx 10 \mu \mathrm{s}$. Then the pulse energy $W_{\mu}$ is defined as the sum of the areas of the selected areas $W_{\mu} \approx U \cdot I \cdot t_{1}+0.5 \cdot U \cdot I \cdot t_{2} \approx$ $\approx 6000 \mathrm{~V} \cdot 0.15 \mathrm{~A} \cdot 10 \cdot 10^{6} \mathrm{~s}+0.5 \cdot 8000 \mathrm{~V} \cdot 0.2 \mathrm{~A} \cdot 10 \cdot 10^{-6} \mathrm{~s} \approx$ $\approx(0.009+0.008) \mathrm{J} \approx 17 \mathrm{~mJ}$.

Oscillograms of Fig. 2, $b$ with nanosecond pulses for the estimated calculation of the pulse energy are divided 
into triangular areas. The first two triangular regions are selected at the front when the current and voltage on the load reach maximum values during $t_{1} \approx 10 \mathrm{~ns}$. To take into account the pulse energy released in the load on the flat part of the pulse decay, we choose the second two triangular regions with duration along the time axis $t_{2} \approx 150 \mathrm{~ns}$, where the amplitudes of voltage and current reach values $U_{2} \approx 6 \mathrm{kV}, I_{2} \approx 6 \mathrm{~A}$, respectively. The energy $W_{n}$ released in each nanosecond pulse, we define as the sum of the areas of selected areas $W_{n} \approx 0.5 \cdot U_{1} \cdot I_{1} \cdot t_{1}+$ $+0.5 \cdot U_{2} \cdot I_{2} \cdot t_{2} \approx\left(0.5 \cdot 30000 \cdot 35 \cdot 10 \cdot 10^{-9}+\right.$ $\left.+0.5 \cdot 6000 \cdot 6 \cdot 150 \cdot 10^{-9}\right) \approx(0.00525+0.0027) \mathrm{J} \approx 7.95 \mathrm{~mJ}$.

The ratio of the energy $W_{\mu}$ released in the load at each microsecond pulse to the energy $W_{n}$ released in the load at each nanosecond pulse in this work is equal to $W_{\mu} / W_{n} \approx 17 / 7.95 \approx 2.1$.

By increasing the electric strength of the discharge gap in gas bubbles at nanosecond pulses, it was possible to obtain pulsed voltages with amplitude of $30 \mathrm{kV}$ on the load. The operation of the circuit without protective resistance, an increase in the electrical strength of the gap and a decrease in the capacitance resistance of water at nanosecond pulses allowed, compared to microsecond pulses, to increase the current amplitude 175 times and to reach its value of $35 \mathrm{~A}$. Therefore, the disinfecting and cleaning action of nanosecond pulses is better than with microsecond pulses. And this is achieved at a significantly lower energy in the nanosecond pulse. In microsecond pulses, most of the energy is consumed less efficiently: the degree of water disinfection is less, and unwanted heating of water is more.

Figures $3, a, b$ show the luminescence at nanosecond and microsecond discharges in gas bubbles in water. It has been established that the intensity of luminescence at nanosecond discharges is greater (see Fig. 3,a) due to the increase in their amplitudes of the pulsed voltage and current in gas bubbles.

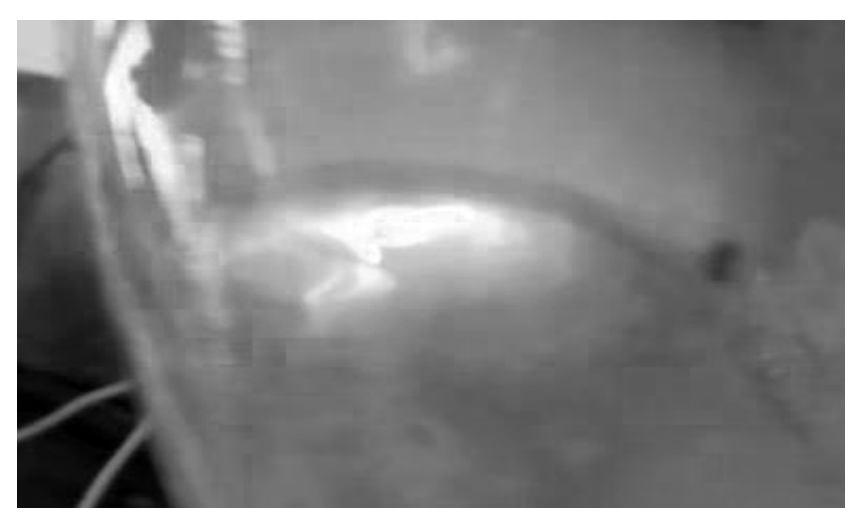

$a$

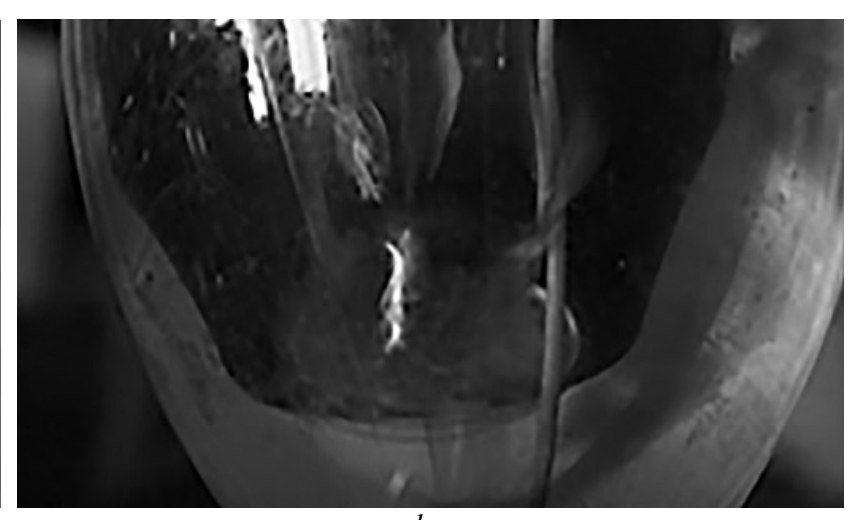

$b$

Fig. 3. Discharges in a gas bubble: $a$ - nanosecond pulses; $b$ - microsecond pulses

A series of experiments on microbiological disinfection and purification of water using micro- and nanosecond discharges in gas bubbles was carried out. During water purification (the sample was taken from the Kharkiv river in a volume of 3 liters) using microsecond discharges in gas bubbles (see Fig. 2,a), the processing time was 10 minutes, the volume of processing was 1.5 liters (three portions of 0.51 each). The treated water was filtered with a paper filter before being sent to the laboratory (Communal Enterprise «Sanepidservice», Kharkiv). Biochemical oxygen consumption decreased from $3.84 \mathrm{mgO}_{2} / \mathrm{dm}^{3}$ (in the control sample) to 3.67 $\mathrm{mgO}_{2} / \mathrm{dm}^{3}$ (in the treated samples), at a rate of $\leq 6 \mathrm{mgO}_{2} / \mathrm{dm}^{3}$, i.e. it was possible to additionally clean the fairly clean source water. The turbidity of water has decreased, the organoleptic properties of water have improved. When processing the water temperature increased by $17-20^{\circ} \mathrm{C}$.

When treating tap water contaminated with E.coli bacteria with a dilution of $10^{8}$ in 3 liters of water (at the Communal Enterprise «Sanepidservice», Kharkiv), using nanosecond discharges (see Fig. 2,b) in gas bubbles, the processing time was 7 minutes, the volume of the processed material 1.51 (three portions of 0.51 ), complete (100\%) inactivation of bacteria has been achieved. The temperature of the treated water increased by $7-8{ }^{\circ} \mathrm{C}$.
The estimated energy released in the load when treating water using discharges in gas bubbles in the case of using nanosecond discharges was about 2.1 times less than when using microsecond discharges. Therefore, the heating of water at nanosecond discharges is also less. The pulse repetition rate was the same for both processing modes, including nano- and microsecond discharges, respectively.

Conclusions. The results of the experiments on the disinfection and purification of water using micro- and nanosecond discharges in gas bubbles showed the promise of further study and practical application of these types of discharges. Nanosecond discharges seem to be more promising for industrial applications. When using nanosecond discharges, complete inactivation of E.coli bacteria is achieved, water heating is insignificant, and the intensity of broadband radiation at such discharges, compared with microsecond discharges, is higher due to large amplitudes of pulsed currents and amplitudes of pulsed electric field strengths. The energy in the pulse with nanosecond discharges is 2.1 times less than with microsecond discharges.

\section{REFERENCES}

1. Gershman S., Mozgina O., Belkind A., Becker K., Kunhardt E. Pulsed Electrical Discharge in Bubbled Water. Contributions 
to Plasma Physics, 2007, vol.47, no. 1-2, pp. 19-25. doi: 10.1002/ctpp.200710004.

2. Boyko N.I., Makogon A.V. Experimental plant for water purification with the help of discharges in gas bubbles. Technical Electrodynamics, 2017, no.5, pp. 89-95. doi: 10.15407/techned2017.05.089.

3. Boyko N.I., Makogon A.V. Generator of high-voltage nanosecond pulses with repetition rate more than 2000 pulses per second for water purification by the discharges in gas bubbles. Technical Electrodynamics, 2018, no.4, pp. 37-40. doi: 10.15407/techned2018.04.037.

4. Boyko M.I., Makogon A.V., Marynin A.I. Energy efficiency of the disinfection treatment of liquid foodstuffs by high-voltage pulse effects. Electrical engineering \& electromechanics, 2018, no.3, pp. 53-60. doi: 10.20998/2074-272X.2018.3.07.

5. Trofimova S.V., Ivanova I.P., Bugrova M.L. The analysis of structural changes of prokaryotic and eukaryotic cell under the influence of plasma spark radiation. Fundamental research, 2013, no.4(part 1), pp. 130-133. (Rus).

6. Ivanova I.P., Trofimova S.V., Piskaryov I.M., Burkhina O.E., Sysoeva V.A., Karpel Vel Leitner N. The Study of Biocidal Mechanisms of Spark Discharge Plasma Radiation. Modern Technologies in Medicine, 2012, no.3, pp. 12-18. (Rus).

How to cite this article:

Boyko M.I., Makogon A.V. The micro- and nanosecond discharges in gas bubbles for water disinfection and purification. Electrical engineering \& electromechanics, 2019, no.3, pp. 50-54. doi: 10.20998/2074-272X.2019.3.08. at: http://www.chem.msu.su/rus/handbook/redox/elem dat/o.html (accessed 13 June 2018). (Rus).

8. Nazarenko O.B, Shubin E.G. Investigation of Electric Discharge Treatment of Water for Ammonium Nitrogen Removal. Proceedings of the 2nd Environmental Physics Conference, 18-22 Feb. 2006, Alexandria, Egypt, pp. 85-90.

9. Iavorovskii N.A., Kornev Ya.I., Preis S.V., Pel'tsman S.S., Khaskel'berg M.B., Chen B.N. Pulsed barrier discharge as a method of water treatment: active particles-oxidizing agents in the water-air flow. Bulletin of the Tomsk Polytechnic University, 2006, vol.309, no.2, pp. 108-113. (Rus).

Received 27.02.2019

M.I. Boyko ${ }^{1}$, Doctor of Technical Science, Professor,

A.V. Makogon ${ }^{1}$, Postgraduate Student,

${ }^{1}$ National Technical University «Kharkiv Polytechnic Institute», 2, Kyrpychova Str., Kharkiv, 61002, Ukraine, phone +380 577076245 ,

e-mail: qnaboyg@gmail.com
7. Available 